\title{
Purification and characterization of a fimbrial protein from Porphyromonas salivosa ATCC 49407
} \author{
Yasunori KOYATA ${ }^{1)}$, Kiyoko WATANABE $^{1)}$, Toshizo TOYAMA ${ }^{1)}$, Haruka SASAKI ${ }^{1)}$
and Nobushiro HAMADA ${ }^{1) *}$ \\ 1)Division of Microbiology, Department of Oral Science, Kanagawa Dental University, Yokosuka, \\ Kanagawa 238-8580, Japan
}

J. Vet. Med. Sci.

81(6): 916-923, 2019

doi: 10.1292/jvms.19-0067

Received: 1 February 2019

Accepted: 11 April 2019

Published online in J-STAGE: 23 April 2019
ABSTRACT. Periodontal disease is a significant problem in companion animals such as dogs and cats. However, there is little information available about fimbriae association of periodontal disease in companion animals. In this study, we have purified and characterized a fimbriae from Porphyromonas salivosa ATCC 49407. The molecular mass of this protein was approximately $60-\mathrm{kDa}$, as estimated by SDS-PAGE. Immunogold electron microscopy revealed that anti-60-kDa fimbrial serum bound to fimbria on the cell surface of $P$. salivosa ATCC 49407. However, fimbriae of $P$. gingivalis and $P$. gulae were not labeled with the same antibody. Immunoelectron-microscopic studies and immunoblot analysis revealed that antigenicity and molecular weight were distinct from previously reported Porphyromonas fimbrial proteins. The amino acid sequence of the $\mathrm{N}$-terminal 15 residues of the 60 -kDa fimbrillin protein revealed only 3 of 15 residues identical to other Porphyromonas species fimbrillin proteins. Thus, the N-terminal amino acid sequence of the $60-\mathrm{kDa}$ fimbrillin protein of $P$. salivosa clearly differed from previously reported fimbrillin proteins. The level of adherence of the $P$. salivosa was $1.81 \%$. It was confirmed that $P$. salivosa can adheres to human cells. These results suggest that the $60-\mathrm{kDa}$ fimbriae of $P$. salivosa ATCC 49407 is a new type of fimbria and may have an important factor in the adherence host cells. We suggest that the surface structure of $P$. salivosa may have a role in the colonization of this organism in periodontal pockets in companion animals.

KEY WORDS: fimbria, periodontitis, Porphyromonas gingivalis, Porphyromonas salivosa, 60-kDa fimbrial protein

Porphyromonas salivosa is a black-pigmented, asaccharolytic, anaerobic, non-motile, non-spore-forming, Gram-negative, rod-shaped organism [30]. In 1987, Love et al. [29] described Bacteroides salivosus as a pigmented asaccharolytic pathogen which was isolated from subcutaneous abscesses and pyothoraxes of cats. B. salivosus strains have little DNA-DNA hybridization with members of previously described pigmented asaccharolytic Bacteroides species. In addition, DNA-DNA hybridization experiments revealed that the levels of hybridization between feline strains and Bacteroides macacae ATCC 33141 [7, 28, 45] are not significant.

Periodontitis in companion animals is an almost identical disease to that in humans in terms of disease course and clinical presentations $[1,8,9,16,26]$. Black-pigmenting anaerobic bacteria have been isolated from the periodontal pockets of several animals. The most frequently isolated black-pigmented anaerobic bacteria in canine periodontal pockets are $P$. gulae, $P$. salivosa and $P$. denticanis $[1,19]$. However, several differences between human and companion animal Porphyromonas isolates have been reported $[9,19]$. P. gingivalis isolates from humans are catalase-negative, whereas $P$. gingivalis-like isolates from canine periodontal pockets are catalase-positive. These catalase-positive $P$. gingivalis-like isolates may be of $P$. gulae.

Periodontal disease is a significant oral problem, characterized by halitosis, gingival inflammation, increased periodontal pocket depth, and alveolar bone loss, which results in loosening and eventual loss of teeth. Periodontal pathogens induce inflammatory reactions in the surrounding tissues $[2,15,23]$.

Periodontitis is accepted as the most common cause of tooth loss in dogs and cats [6]. Numerous investigators have shown that periodontal disease in dogs and humans is accompanied by a shift in oral bacterial flora from predominantly aerobic Gram-positive bacteria to anaerobic Gram-negative rods $[17,18,27,37,44]$. Studies on feline periodontal disease have shown that the proportions of Gram-negative rods increase as the degree of periodontal disease increase and conversely found a negative correlation between

*Correspondence to: Hamada, N.: hamada@kdu.ac.jp

O2019 The Japanese Society of Veterinary Science

This is an open-access article distributed under the terms of the Creative Commons Attribution Non-Commercial No Derivatives (by-nc-nd) License. (CC-BY-NC-ND 4.0: https://creativecommons.org/licenses/by-nc-nd/4.o/) 
the degree of periodontal disease and the number of facultative/aerobic Gram-positive rods [36]. Porphyromonas gingivalis is an obligate anaerobic Gram-negative coccobacillus that has been associated with periodontal destruction in humans [23]. The feline Porphyromonas species, P. circumdentaria and P. salivosa were isolated from oral-associated diseases in domestic cats and from normal gingival margins of adolescent cats [31-35]. Moreover, Porphyromonas-like Gram-negative rods resembling human strains of $P$. gingivalis, $P$. endodontalis and feline strains of $P$. salivosa were isolated from dogs with periodontitis [5, 21, 43]. These findings suggested that Porphyromonas species had an ecological niche within the feline oral cavity.

Human periodontitis has been associated with subgingival plaque containing elevated levels of a specific Gram-negative anaerobic bacteria. $P$. gingivalis is a pathogen that causes periodontal disease, which is a typical chronic inflammatory disease $[10,23,25,47]$. Bacterial fimbria is an important cell structure that contributes to the adherence and invasion of host cells $[3,20,24,42,48]$, and induces inflammatory processes in periodontal tissues through a number of mechanisms $[2,11] . P$. gingivalis fimbriae bind specifically to components lining the oral cavity, such as salivary proteins, commensal bacteria, several types of extracellular matrices, and host cells, including gingival fibroblasts, epithelial cells, and endothelial cells [15]. These adhesive abilities are a pathogenic trait that causes periodontal tissue destruction [38]. Moreover, fimbriae function as virulence factors in inflammatory reactions because they stimulate the production of inflammatory cytokines by macrophages and fibroblasts. These observations suggest the involvement of fimbriae as regulators of inflammatory reactions caused by bacterial infection [42].

In humans, much progress has been made in understanding the disease etiology and interaction between host and periodontal pathogens. These pathogens possess virulence factors that include collagenase, lipopolysaccharides, a trypsin-like protease and fimbriae [23]. Fimbriae in particular have an important role in facilitating the initial interaction between the bacteria and host $[3,14,49]$. In this study, to clarify the presence of new type of fimbriae in Porphyromonas species, we purified and characterized a fimbrial protein from $P$. salivosa ATCC 49407.

\section{MATERIALS AND METHODS}

\section{Strains and cultivation conditions}

P. salivosa ATCC 49407, P. gingivalis ATCC 33277 and P. gulae ATCC 51700 were cultivated $\left(15 \% \mathrm{CO}_{2}, 15 \% \mathrm{H}_{2}\right.$ and $\left.70 \% \mathrm{~N}_{2}\right)$ in an anaerobic chamber (ANX-1; HIRASAWA, Tokyo, Japan) at $37^{\circ} \mathrm{C}$ in pre-reduced brain heart infusion (BHI) broth (Becton Dickinson Co., Sparks, MD, U.S.A.) supplemented with 0.5\% yeast extract (Becton Dickinson Co.), $5 \mu \mathrm{g} / \mathrm{m} l \mathrm{hemin}$ (SigmaAldrich, St. Louis, MO, U.S.A.), and $1 \mu \mathrm{g} / \mathrm{m} l$ vitamin $\mathrm{K}_{1}$ (Sigma-Aldrich).

\section{Isolation and purification of the 60-kDa fimbriae from P. salivosa}

P. salivosa was incubated anaerobically for $18 \mathrm{hr}$ in BHI broth. The bacterial cell pellet was harvested by centrifugation at 8,000 $\times \mathrm{g}$ for $30 \mathrm{~min}$ and washed twice with $20 \mathrm{mM}$ Tris- $\mathrm{HCl}$ buffer $(\mathrm{pH} 8.0)$ containing $10 \mathrm{mM} \mathrm{MgCl}_{2}$ and $0.15 \mathrm{M} \mathrm{NaCl}$ by repeated pipetting. The suspension was subjected to ultrasonication with a 3-mm microtip (Branson Ultrasonics Corporation, Danbury, CT, U.S.A.) at $25 \mathrm{~W}$ output on the pulse setting with 5 cycles of $1 \mathrm{~min}$ in an icebox. The supernatant of the sonic extract collected by centrifugation at $10,000 \times \mathrm{g}$ for 30 min was subjected to $40 \%$ ammonium sulfate saturation by the stepwise addition of ammonium sulfate. The precipitated protein was collected by centrifugation at $10,000 \times \mathrm{g}$ for $30 \mathrm{~min}$ at $4^{\circ} \mathrm{C}$, suspended in a minimum volume of $20 \mathrm{mM}$ Tris buffer, $\mathrm{pH}$ 8.0, and dialyzed against the same buffer. The dialysate sample containing most of the fimbriae was subjected to further purification on a diethylaminoethyl (DEAE) Sepharose CL-6B (GE Healthcare Bio-Sciences, Pittsburgh, PA, U.S.A.) column equilibrated with $20 \mathrm{mM}$ Tris buffer ( $\mathrm{pH} \mathrm{8.0)}$ ). The column was washed with $20 \mathrm{mM}$ Tris buffer and then eluted with a linear gradient of $0 \mathrm{M}$ to $0.3 \mathrm{M} \mathrm{NaCl}$. The protein content of the fractions was measured by ultraviolet light adsorption at $280 \mathrm{~nm}$.

\section{Sodium dodecyl sulfate polyacrylamide gel electrophoresis (SDS-PAGE)}

Protein extracts were heated at $100^{\circ} \mathrm{C}$ for $5 \mathrm{~min}$ in loading buffer. Samples were applied to $12.0 \%$ polyacrylamide gel with a $4 \%$ stacking gel, and electrophoresed at $30 \mathrm{~mA}$ constant current for $1 \mathrm{hr}$. The proteins were stained with Coomassie brilliant blue R-250 (Bio-Rad Laboratories, Inc. Hercules, CA, U.S.A.). For molecular weight calibration, a low-molecular weight marker kit (ATTO, Tokyo, Japan) was used.

\section{Polyclonal antibodies}

Polyclonal antibodies (PAbs) against the $60-\mathrm{kDa}$ fimbrial protein were prepared using the purified protein described above as an immunogen. BALB/c mice (Nihon SLC, Inc., Shizuoka, Japan) were injected at multiple sites subcutaneously with $50 \mu \mathrm{g}$ of the $60-\mathrm{kDa}$ fimbrial protein emulsified with Freund's incomplete adjuvant (Becton Dickinson Co.). After 2 weeks, the mice were injected weekly for 4 weeks with the immunogen. Each mouse was bled after the last booster injection, and the antibodies were tested against the corresponding antigen by western blotting. After an adequate antibody titer was obtained, the mice were bled by cardiac puncture and the sera were prepared and stored at $-20^{\circ} \mathrm{C}$. The experimental procedures were reviewed and approved by the Committee of Ethics on Animal Experiments of Kanagawa Dental University.

\section{Western blotting}

For immunoblot analysis, the proteins separated by $12 \%$ SDS-PAGE were transferred to a PVDF membrane (Immun-Blot ${ }^{\circledR}$ PVDF Membrane; Bio-Rad Laboratories) at $200 \mathrm{~mA}$ for $1 \mathrm{hr}$. The membranes were then treated with Tris-buffered saline (TBS; $20 \mathrm{mM}$ Tris- $\mathrm{HCl} \mathrm{pH} 7.4,0.5 \mathrm{M} \mathrm{NaCl}$ ) containing 1\% bovine serum albumin (BSA; Sigma-Aldrich) to block unoccupied protein 
binding sites. They were then incubated with the PAbs specific for the $60-\mathrm{kDa}$ fimbrial protein at $37^{\circ} \mathrm{C}$ for $1 \mathrm{hr}$, washed in TBSTween (TBS with $0.5 \%$ Tween 20), incubated for $1 \mathrm{hr}$ with goat anti-mouse immunoglobulin G conjugated with horseradish peroxidase (R\&D Systems, Inc., Minneapolis, MN, U.S.A.), and then immersed in 4-chloro-1-naphthol (Tokyo Chemical Industry, Tokyo, Japan) solution to develop the color. The reaction was stopped by immersing the membranes in distilled water, and the membranes were then dried.

\section{Electron microscopy}

The fimbriae of bacterial cell surfaces were examined with a transmission electron microscope. Bacterial cells from an 18-hr anaerobic culture were collected by centrifugation $(10,000 \times \mathrm{g}$ for $1 \mathrm{~min})$, washed, and resuspended $\left(5 \times 10^{8} / \mathrm{m} l\right)$ in phosphatebuffered saline ( $\mathrm{pH}$ 7.4). Ten microliters of the cell suspension or purified fimbriae was applied on a copper grid coated with a thin Formvar film and air-dried. The samples were then negatively stained with $2 \%(\mathrm{wt} / \mathrm{vol})$ uranyl acetate for $1 \mathrm{~min}$, air-dried, examined, and photographed with a JEM-1220 electron microscope (JEOL Ltd., Tokyo, Japan) operating at $80 \mathrm{kV}$.

\section{Immunoelectron microscopy}

Bacterial cells from 18-hr anaerobic culture were harvested by centrifugation at 10,000 $\times \mathrm{g}$ for $1 \mathrm{~min}$, and resuspended in phosphate-buffered saline (PBS, pH 7.4). Copper grids (Maxtaform Grid HR24; Nisshin EM, Tokyo, Japan) were covered with a thin film of collodion (Nisshin EM), which was then coated with carbon. The supported films were made hydrophilic by ion bombardment before use. A drop of cell suspension or purified protein was applied to the specimen grid. For immunogold labeling, a cell suspension was transferred to a collodion-coated film copper grid. The samples were incubated with $10 \mu l$ mouse PAbs against the $60-\mathrm{kDa}$ fimbrial protein of $P$. salivosa ATCC 49407 (diluted 1:5,000 in PBS containing $1 \% \mathrm{BSA}$ ) at $37^{\circ} \mathrm{C}$ for $1 \mathrm{hr}$. After five washes with PBS, the samples were incubated with EM goat anti-mouse IgG: 5-nm gold (BBI Solutions, Cardiff, U.K.) at $37^{\circ} \mathrm{C}$ for $30 \mathrm{~min}$. The samples were then negatively stained with $2 \%$ uranyl acetate for $1 \mathrm{~min}$. The specimens were examined and photographed with a JEM-1220 electron microscope (Nippon Denshi Co., Tokyo, Japan) operated at $80 \mathrm{kV}$.

\section{$N$-terminal amino acid sequences}

Purified fimbrial protein was electrophoresed on a 12\% SDS-polyacrylamide gel and then transferred onto a PVDF membrane operated at $200 \mathrm{~mA}$ for $1 \mathrm{hr}$. After the membrane was stained with Coomassie brilliant blue R-250, the purified fimbrial protein band was excised and analyzed using a PPSQ-33a amino acid sequencer system (Shimadzu, Kyoto, Japan).

\section{Adherence assay}

Human gingival epithelial cells (HGECs) were obtained from the dental patient. Adherence of HGECs by $P$. salivosa and $P$. gingivalis was assessed as follows. Bacterial cells were collected by centrifugation, washed with keratinocyte growth medium (KGM, LONZA, Walkersville, MD, U.S.A.), and re-suspended in KGM at a final concentration of $10^{9}$ cells $/ \mathrm{ml}$. Bacterial suspensions were added to confluent HGECs monolayers at a multiplicity of infection (MOI) of 100 and then incubated at $37^{\circ} \mathrm{C}$ in $5 \% \mathrm{CO}_{2}$ for $90 \mathrm{~min}$. After incubation, unattached bacteria were removed by sterile PBS twice. HGECs were lysed in $1 \mathrm{~m} l$ of sterile distilled water per well and incubated for $30 \mathrm{~min}$. Lysates were serially diluted, placed on BHI blood agar plates and incubated anaerobically at $37^{\circ} \mathrm{C}$ for 7 days. All assays were performed in triplicate. Adherence capacities of the bacterial strains were calculated from the colony forming units (CFU) recovered as a percentage of total bacteria bound to HGEC. The experimental procedures, were approved by the Ethical Committee of Kanagawa Dental University.

\section{Statistical analysis}

Data comparisons between the two groups were analyzed by a Student's $t$-test. A value of $P<0.05$ was considered significant. Computations were performed using a statistical software program (STATVIEW version 5.0; Abacus Concepts, Inc., Berkeley, CA, U.S.A.).

\section{RESULTS}

\section{Isolation and purification of the 60-kDa fimbriae from P. salivosa}

The fraction containing fimbrial protein was obtained from the crude fimbrial preparation of $P$. salivosa ATCC 49407 using a DEAE Sepharose CL-6B anion exchange column. The protein showed a single band with a molecular mass of 60-kDa by SDSPAGE (Fig. 1). Fimbrial protein was purified using DEAE-Sepharose CL-6B column chromatography and was detected as a major component of the main peak eluted at $0.15 \mathrm{M} \mathrm{NaCl}$. Negative staining revealed that the fraction eluted at $0.15 \mathrm{M} \mathrm{NaCl}$ was a dense network of fimbrial structures (Fig. 2). To confirm the presence of the 60-kDa fimbrial protein in P. salivosa ATCC 49407, wholecell lysates prepared from $P$. salivosa ATCC 49407, P. gingivalis ATCC 33277 and $P$. gulae ATCC 51700 were analyzed by SDSPAGE followed by Coomassie staining and western blotting with PAbs against the $60-\mathrm{kDa}$ fimbrial protein. By western blotting analysis, the PAbs against the fimbrial protein from $P$. salivosa ATCC 49407 reacted with only whole-cell lysates prepared from $P$. salivosa ATCC 49407, but did not react with whole-cell lysates prepared from P. gingivalis ATCC 33277 and $P$. gulae ATCC 51700 (Fig. 3). Fimbrial structures were observed on the cell surface of $P$. salivosa ATCC 49407 by transmission electron microscopy using the negative staining technique (Fig. 4a). The fimbria was $0.3 \pm 0.2 \mu \mathrm{m}$ in length and $5 \mathrm{~nm}$ in width, which is shorter than the 41-kDa fimbria of $P$. gingivalis ATCC 33277. 


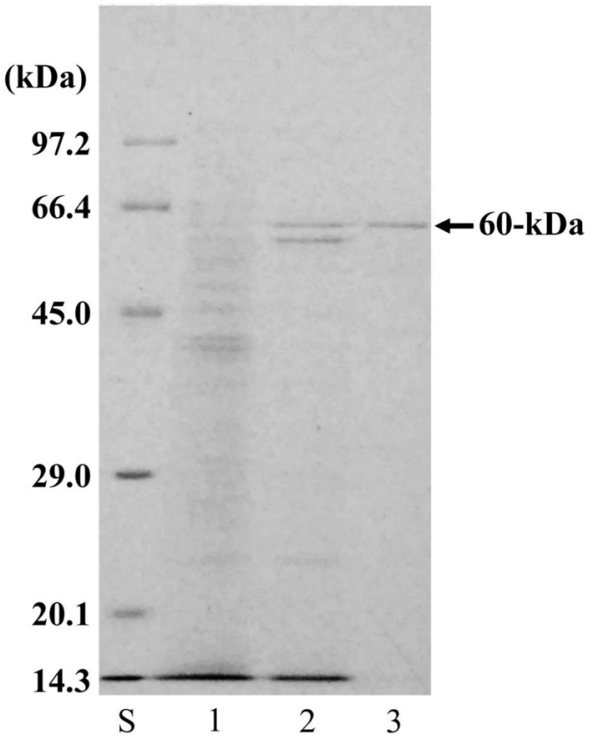

Fig. 1. SDS-PAGE analysis of purified fimbriae isolated from Porphyromonas salivosa ATCC 49407. The fimbriae were then electrophoresed on a $12 \%$ SDS-polyacrylamide gel and stained with Coomassie brilliant blue R-250. Lanes: S, standard proteins; 1, whole cell of $P$. salivosa ATCC 49407; 2, sonic extract of $P$. salivosa ATCC 49407; 3, purified 60-kDa fimbriae.

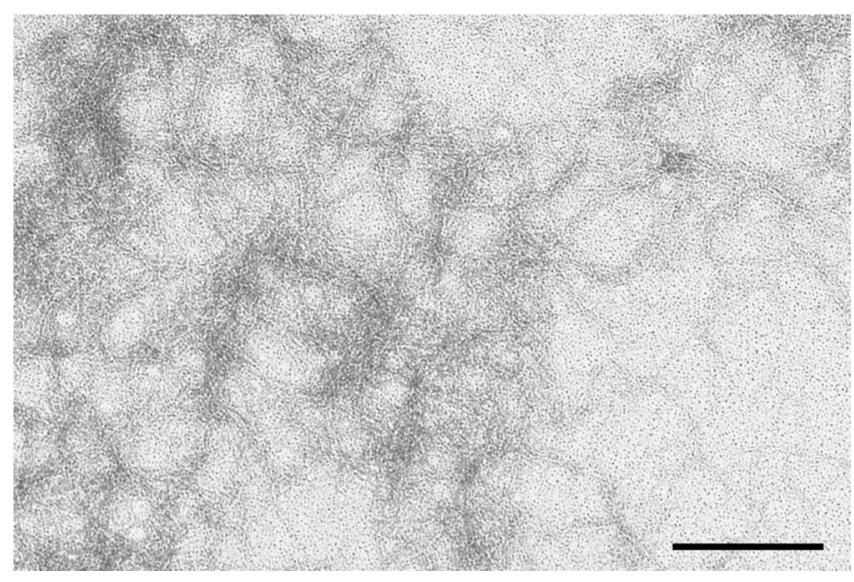

Fig. 2. Electron micrograph of purified fimbriae. The purified protein from Porphyromonas salivosa ATCC 49407 was observed fimbrial structures. Bar, $0.2 \mu \mathrm{m}$.
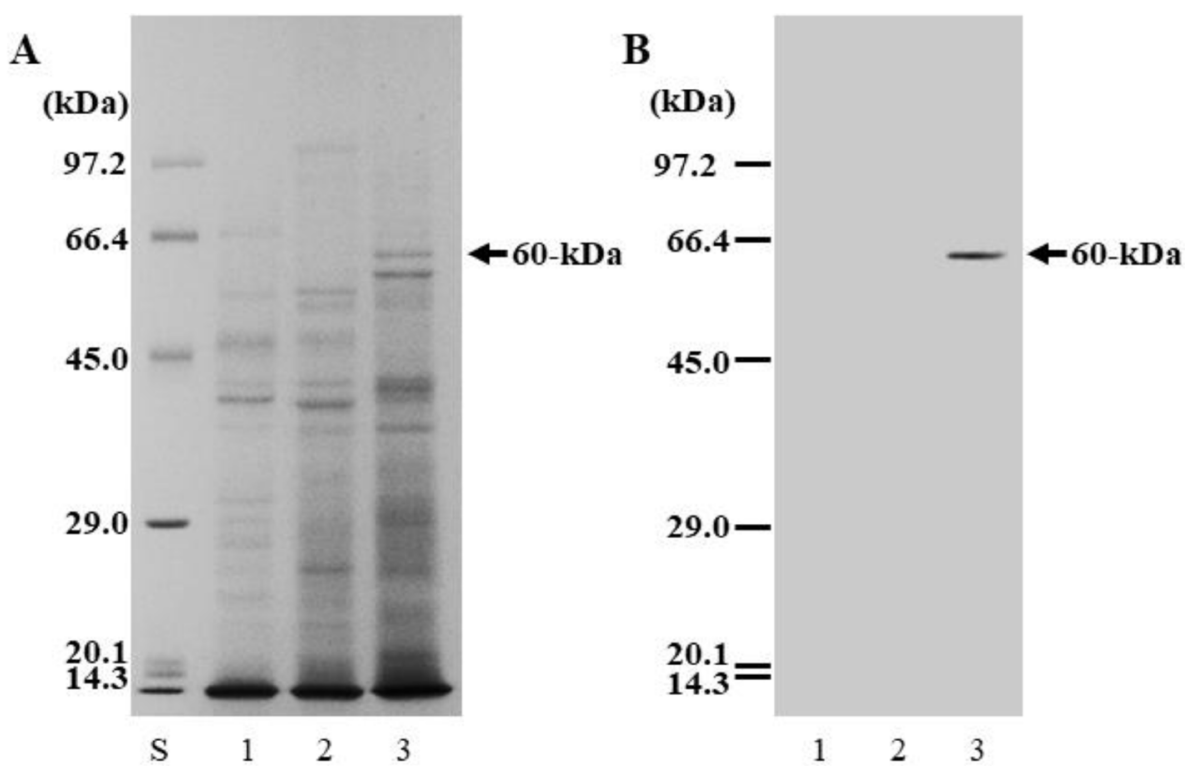

Fig. 3. Western blot analysis of Porphyromonas salivosa fimbriae. SDS-PAGE analysis of whole cells of Porphyromonas species (A). The SDS-PAGE was electrophoretically transferred to a nitrocellulose membrane and incubated with a 60-kDa PAbs (B). The PAbs specific for the $60-\mathrm{kDa}$ fimbriae strongly reacted with $P$. salivosa. Lanes: $\mathrm{S}$, Standard proteins; 1 , P. gingivalis ATCC 33277; 2, P. gulae ATCC 51700; 3, P. salivosa ATCC 49407.

\section{Transmission electron micrograph of immunogold labeling}

The expression of fimbriae on the cell surface of $P$. salivosa ATCC 49407 was investigated by transmission electron microscopy (Fig. 4a). By immunogold labeling, the fimbriae of $P$. salivosa ATCC 49407 were labeled with PAbs against the 60-kDa protein (Fig. 4b). However, gold particles were not bound to fimbriae of $P$. gingivalis and $P$. gulae (Fig. 5c and 5d). These results suggested that $P$. salivosa ATCC 49407 had only a 60-kDa fimbria. 

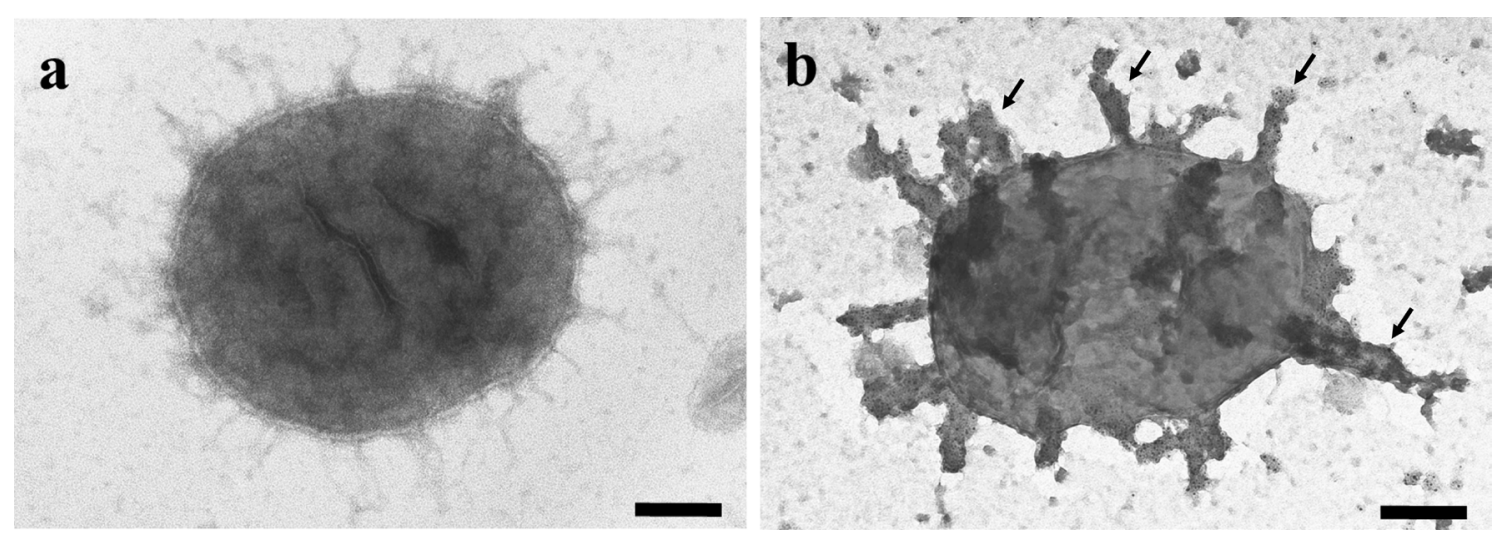

Fig. 4. Electron micrographs of Porphyromonas salivosa ATCC 49407 . Bacterial cells were cultured at $37^{\circ} \mathrm{C}$ anaerobically and negatively stained with $2 \%$ uranyl acetate. P. salivosa ATCC 49407 possessed fimbriae on its surface (a). Cells were incubated with the $60-\mathrm{kDa}$ PAbs and then with $5 \mathrm{~nm}$ of colloidal gold-labeled goat anti-mouse serum. Samples were prepared by negative staining with $2 \%$ uranyl acetate. The fimbriae on the surface were labeled with the $60-\mathrm{kDa}$ PAbs (arrows) (b). Bars, $0.2 \mu \mathrm{m}$.
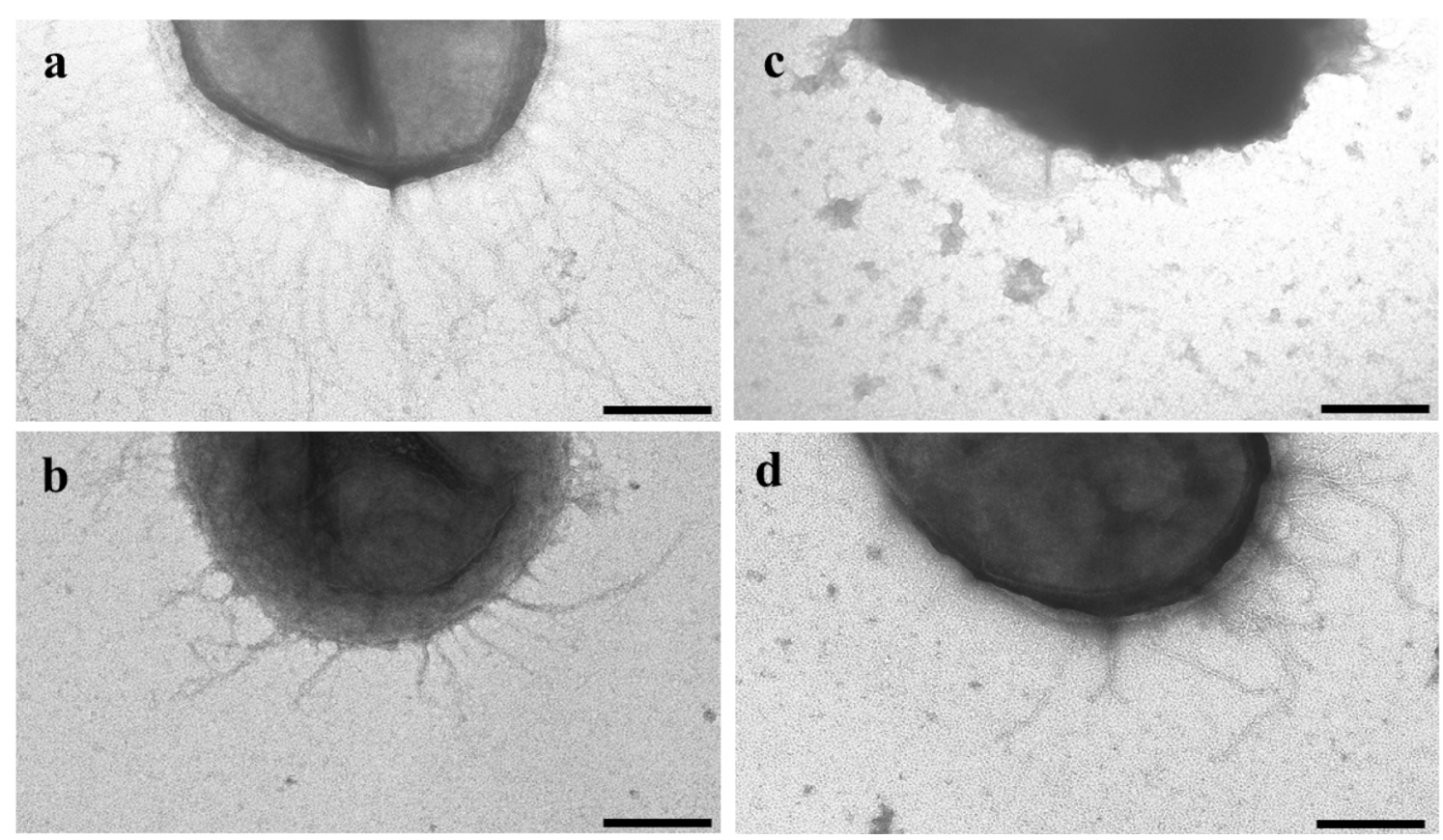

Fig. 5. Localization of the $60-\mathrm{kDa}$ fimbriae on a whole cell by immunogold electron microscopy. Bacterial cells were incubated with the $60-\mathrm{kDa}$ PAbs. After washing with PBS, cells were incubated with goat anti-mouse immunoglobulin G conjugated with 5-nm gold particles. The fimbriae on the surface of Porphyromonas gingivalis and $P$. gulae were not labeled with the 60-kDa PAbs. P. gingivalis ATCC 3277 (a, c). P. gulae ATCC 51700 (b, d). Negative staining (a, b). Immunogold (c, d). Bars, $0.2 \mu \mathrm{m}$.

\section{Comparison of N-terminal amino acids}

The amino acid sequence of the N-terminal 15 residues of the 60-kDa fimbrillin protein from P. salivosa ATCC 49407 and from other Porphyromonas species are shown in Table 1. The amino acid sequence of the N-terminal 15 residues of the 60-kDa fimbrillin protein (ANADGQDKPNPDFNY) had 3 of 15 residues that were the same as those of the P. gingivalis ATCC 3327741 $\mathrm{kDa}$ fimbrillin protein (AFGVGDDESKVAKLT), and 2 of 15 residues that were the same as those of the $P$. gulae 41-kDa fimbrillin protein (AFGVADDEAKVAKLTY). Furthermore, the 60-kDa fimbrillin protein-showed that only 1 of 15 residues were the same as those of the $P$. gingivalis $67-\mathrm{kDa}$ fimbrillin protein, $53-\mathrm{kDa}$ fimbrillin protein and $P$. gulae $53-\mathrm{kDa}$ fimbrillin protein. The $\mathrm{N}$-terminal amino acid sequence of the 60-kDa fimbrillin protein of $P$. salivosa clearly differed from previously reported fimbrillin proteins $[4,12,13,41,48]$ (Table 1).

\section{Adherence of P. salivosa to HGEC}

Fimbriated $P$. gingivalis strains can bind to epithelial cells from human gingival tissues. Therefore, the ability of $P$. salivosa to 
Table 1. The amino acid sequences of the N-terminal 15 residues of Porphyromonas species Fimbrillin

\begin{tabular}{|c|c|c|c|c|c|c|c|c|c|c|c|c|c|c|c|c|c|}
\hline \multirow{2}{*}{$\begin{array}{c}\text { Strain } \\
\text { P. salivosa ATCC } 49407\end{array}$} & \multirow{2}{*}{$\begin{array}{c}\text { Fimbriae } \\
60 \mathrm{~K}\end{array}$} & \multicolumn{15}{|c|}{ Amino acid sequence } & \multirow[t]{2}{*}{$\begin{array}{c}\text { Homology } \\
(\%)\end{array}$} \\
\hline & & A & $\mathrm{N}$ & A & $\mathrm{D}$ & G & Q & $\mathrm{D}$ & $\mathrm{K}$ & $\mathrm{P}$ & $\mathrm{N}$ & $\mathrm{P}$ & $\mathrm{D}$ & $\mathrm{F}$ & $\mathrm{N}$ & Y & \\
\hline \multirow{2}{*}{ P. gingivalis ATCC 33277} & $41 \mathrm{~K}$ & A & $\mathrm{F}$ & G & $\mathrm{V}$ & G & $\mathrm{D}$ & $\mathrm{D}$ & $\mathrm{E}$ & $\mathrm{S}$ & $\mathrm{K}$ & $\mathrm{V}$ & A & $\mathrm{K}$ & $\mathrm{L}$ & $\mathrm{T}$ & 20.0 \\
\hline & $67 \mathrm{~K}$ & A & G & $\mathrm{D}$ & G & Q & $\mathrm{D}$ & Q & $\mathrm{A}$ & $\mathrm{N}$ & $\mathrm{P}$ & $\mathrm{D}$ & Y & $\mathrm{H}$ & $\mathrm{Y}$ & $\mathrm{V}$ & 6.7 \\
\hline \multirow{2}{*}{ P. gingivalis 381} & $41 \mathrm{~K}$ & A & $\mathrm{F}$ & G & $\mathrm{V}$ & G & $\mathrm{D}$ & $\mathrm{D}$ & $\mathrm{E}$ & $\mathrm{S}$ & $\mathrm{K}$ & $\mathrm{V}$ & A & K & $\mathrm{L}$ & $\mathrm{T}$ & 20.0 \\
\hline & $53 \mathrm{~K}$ & A & G & $\mathrm{D}$ & $\mathrm{N}$ & $\mathrm{D}$ & $\mathrm{Y}$ & $\mathrm{N}$ & $\mathrm{P}$ & I & G & $\mathrm{E}$ & $\mathrm{Y}$ & G & G & $\mathrm{V}$ & 6.7 \\
\hline \multirow[t]{2}{*}{ P. gulae ATCC 51700} & $41 \mathrm{~K}$ & A & $\mathrm{F}$ & G & $\mathrm{V}$ & $\mathrm{A}$ & $\mathrm{D}$ & $\mathrm{D}$ & $\mathrm{E}$ & $\mathrm{A}$ & K & $\mathrm{V}$ & A & $\mathrm{K}$ & $\mathrm{L}$ & $\mathrm{T}$ & 13.3 \\
\hline & $53 \mathrm{~K}$ & A & $\mathrm{G}$ & D & $\mathrm{N}$ & D & $\mathrm{Y}$ & $\mathrm{N}$ & $\mathrm{H}$ & V & $\mathrm{G}$ & E & $\mathrm{Y}$ & $\mathrm{G}$ & G & V & 6.7 \\
\hline
\end{tabular}

adhere HGEC was examined. The levels of adherence of the $P$. salivosa and $P$. gingivalis were 1.81 and $2.58 \%$, respectively, at a multiplicity of infection (MOI) of 100. P. salivosa ATCC 49407 was statistically less adherent to cultured cells than $P$. gingivalis ATCC 33277 (Fig. 6).

\section{DISCUSSION}

We purified and characterized the fimbrial protein of $P$. salivosa ATCC 49407. The purified fimbrial protein was observed as a single band of $60-\mathrm{kDa}$ by SDS-PAGE analysis, and had antigenicity distinct from that of the fimbrial proteins of $P$. gingivalis and $P$. gulae (Fig. 3). The $\mathrm{N}$-terminal amino acid sequence of the $60-\mathrm{kDa}$ and $41-\mathrm{kDa}$ fimbrillin proteins were identical at only 3 of 15 positions. By immunogold labeling, PAbs against the $60-\mathrm{kDa}$ protein bound to fimbrial structures on the surface of $P$. salivosa ATCC 49407 (Fig. 4b). However, no reaction was observed in the protein band of $P$. gingivalis and $P$. gulae (Fig. 3). These indicated that the $60-\mathrm{kDa}$ protein was not expressed by $P$. gingivalis and P. gulae. P. salivosa ATCC 49407 was less adherent to HGECs than were $P$. gingivalis ATCC 33277 is considered to be due to the difference in fimbrillin protein (Fig. 6, Table 1).

Indeed, Hamada et al. reported that $P$. gulae can bind to human oral epithelial cells in vitro. $P$. gulae ATCC 51700 had the same size and antigenicity as $41-\mathrm{kDa}$ fimbriae of $P$. gingivalis ATCC 33277. The nucleotide sequence of the fimA gene from $P$. gulae ATCC 51700 showed 94\% homology with that of $P$. gingivalis ATCC 33277 . Moreover, the deduced amino acid sequences have $96.8 \%$ identity [13]. These findings suggest that binding sites involved in the interaction with the human host cell not present in $P$. salivosa fimbrillin protein. However, adhesion factors involve not only fimbriae but also other factors. It is necessary to consider that other cell adhesion factors affect the amount of adhesion of bacteria to host cells.

$P$. gingivalis fimbriae are classified into six types (types $\mathrm{I}$ to $\mathrm{V}$ and $\mathrm{Ib}$ ) based on different nucleotide sequences of the fimA genes encoding the 41-kDa fimbrillin protein [3]. The 41-kDa fimbriae bind specifically to and activate various host cells such as human epithelial cells, endothelial cells, spleen cells, and peripheral blood monocytes, which results in the release of cytokines including interleukin-1 (IL-1), IL-6, IL-8, and tumor necrosis factor- $\alpha$ (TNF- $\alpha)[15,24,40]$, as well as cell adhesion molecules including intercellular adhesion molecule 1 (ICAM-1), vascular cell adhesion molecule 1 (VCAM-1), and the P- and E-selectins [22, 39]. The fimbriae of $P$. gingivalis induce inflammatory cytokines in human gingival fibroblasts and murine peritoneal macrophages and promote the adherence of the organism to host tissues. The level of adherence of the $P$. salivosa was $1.81 \%$. The assay for adherence of $P$. salivosa to epithelial cells measured both adherence and invasion after 90 min incubation. It was confirmed that $P$. salivosa could adheres to human cells.

Umemoto et al. [46] demonstrated the importance of $P$. gingivalis FimA for the adherence of the protein to oral cells and alveolar bone loss in rats, using a fimbrial gene-knockout mutant strain. P. gingivalis wild-type was more adherent to human gingival epithelial cells than $P$. gingivalis fimA-knockout mutant MPG1. However, the mean CEJ-to-ABC distance of rats infected with the MPG1 strain was significantly reduced compared to that of rats infected with the wild-type strain. The contribution of $P$. gingivalis to alveolar bone loss is supported by stimulation of osteoclasts, which induces bone destruction and inhibits bone formation. The fimbriae are required for initial attachment and biofilm formation. We think that $P$. salivosa fimbrial protein may induce of osteoclast differentiation, and inflammatory cytokine production in murine peritoneal macrophages. Future studies will be directed toward elucidating the biochemical and immunobiological functions of $60-\mathrm{kDa}$ fimbrial proteins. 
ACKNOWLEDGMENT. This study was supported by a Grant-in-Aid for Scientific Research (C) No. 26462801 from the Japan Society for the Promotion of Science.

\section{REFERENCES}

1. Allaker, R. P., de Rosayro, R., Young, K. A. and Hardie, J. M. 1997. Prevalence of Porphyromonas and Prevotella species in the dental plaque of dogs. Vet. Rec. 140: 147-148. [Medline] [CrossRef]

2. Amano, A. 2010. Bacterial adhesins to host components in periodontitis. Periodontol. 2000 52: 12-37. [Medline] [CrossRef]

3. Amano, A., Nakagawa, I., Okahashi, N. and Hamada, N. 2004. Variations of Porphyromonas gingivalis fimbriae in relation to microbial pathogenesis. J. Periodontal Res. 39: 136-142. [Medline] [CrossRef]

4. Arai, M., Hamada, N. and Umemoto, T. 2000. Purification and characterization of a novel secondary fimbrial protein from Porphyromonas gingivalis strain 381. FEMS Microbiol. Lett. 193: 75-81. [Medline] [CrossRef]

5. Boyce, E. N., Ching, R. J. W., Logan, E. I., Hunt, J. H., Maseman, D. C., Gaeddert, K. L., King, C. T., Reid, E. E. and Hefferren, J. J. 1995. Occurrence of gram-negative black-pigmented anaerobes in subgingival plaque during the development of canine periodontal disease. Clin. Infect. Dis. 20 Suppl 2: S317-S319. [Medline] [CrossRef]

6. Colmery, B. 3rd. and Frost, P. 1986. Periodontal disease. Etiology and pathogenesis. Vet. Clin. North Am. Small Anim. Pract. 16: 817-833. [Medline] [CrossRef]

7. Coykendall, A. L., Kaczmarek, F. S. and Slots, J. 1980. Genetic Heterogeneity in Bacteroides asaccharolyticus (Holdeman and Moore 1970) Finegold and Barnes 1977 (Approved Lists, 1980) and Proposal of Bacteroides gingivalis sp. nov. and Bacteroides macacae (Slots and Genco) comb. nov. Int. J. Syst. Bacteriol. 30: 559-564. [CrossRef]

8. do Nascimento Silva, A., de Avila, E. D., Nakano, V. and Avila-Campos, M. J. 2017. Pathogenicity and genetic profile of oral Porphyromonas species from canine periodontitis. Arch. Oral Biol. 83: 20-24. [Medline] [CrossRef]

9. Fournier, D., Mouton, C., Lapierre, P., Kato, T., Okuda, K. and Ménard, C. 2001. Porphyromonas gulae sp. nov., an anaerobic, gram-negative coccobacillus from the gingival sulcus of various animal hosts. Int. J. Syst. Evol. Microbiol. 51: 1179-1189. [Medline] [CrossRef]

10. Genco, C. A., Van Dyke, T. and Amar, S. 1998. Animal models for Porphyromonas gingivalis-mediated periodontal disease. Trends Microbiol. 6: 444-449. [Medline] [CrossRef]

11. Hajishengallis, G., Wang, M., Liang, S., Shakhatreh, M. A., James, D., Nishiyama, S., Yoshimura, F. and Demuth, D. R. 2008. Subversion of innate immunity by periodontopathic bacteria via exploitation of complement receptor-3. Adv. Exp. Med. Biol. 632: 203-219. [Medline]

12. Hamada, N., Sojar, H. T., Cho, M. I. and Genco, R. J. 1996. Isolation and characterization of a minor fimbria from Porphyromonas gingivalis. Infect. Immun. 64: 4788-4794. [Medline]

13. Hamada, N., Takahashi, Y., Watanabe, K., Kumada, H., Oishi, Y. and Umemoto, T. 2008. Molecular and antigenic similarities of the fimbrial major components between Porphyromonas gulae and P. gingivalis. Vet. Microbiol. 128: 108-117. [Medline] [CrossRef]

14. Hamada, N., Watanabe, K., Sasakawa, C., Yoshikawa, M., Yoshimura, F. and Umemoto, T. 1994. Construction and characterization of a fimA mutant of Porphyromonas gingivalis. Infect. Immun. 62: 1696-1704. [Medline]

15. Hamada, S., Amano, A., Kimura, S., Nakagawa, I., Kawabata, S. and Morisaki, I. 1998. The importance of fimbriae in the virulence and ecology of some oral bacteria. Oral Microbiol. Immunol. 13: 129-138. [Medline] [CrossRef]

16. Hardham, J., Dreier, K., Wong, J., Sfintescu, C. and Evans, R. T. 2005. Pigmented-anaerobic bacteria associated with canine periodontitis. Vet. Microbiol. 106: 119-128. [Medline] [CrossRef]

17. Hennet, P. R. and Harvey, C. E. 1991. Aerobes in periodontal disease in the dog: a review. J. Vet. Dent. 8: 9-11. [Medline]

18. Hennet, P. R. and Harvey, C. E. 1991. Anaerobes in periodontal disease in the dog: a review. J. Vet. Dent. 8: 18-21. [Medline]

19. Isogai, H., Kosako, Y., Benno, Y. and Isogai, E. 1999. Ecology of genus Porphyromonas in canine periodontal disease. Zentralbl. Veterinarmed. B. 46: 467-473. [Medline]

20. Iwashita, N., Nomura, R., Shirai, M., Kato, Y., Murakami, M., Matayoshi, S., Kadota, T., Shirahata, S., Ohzeki, L., Arai, N., Yasuda, J., Yasuda, H., Inaba, H., Matsumoto-Nakano, M., Nakano, K. and Asai, F. 2019. Identification and molecular characterization of Porphyromonas gulae fimA types among cat isolates. Vet. Microbiol. 229: 100-109. [Medline] [CrossRef]

21. Karjalainen, J., Kanervo, A., Väisänen, M. L., Forsblom, B., Sarkiala, E. and Jousimies-Somer, H. 1993. Porphyromonas-like gram-negative rods in naturally occurring periodontitis in dogs. FEMS Immunol. Med. Microbiol. 6: 207-212. [Medline] [CrossRef]

22. Khlgatian, M., Nassar, H., Chou, H. H., Gibson, F. C. 3rd. and Genco, C. A. 2002. Fimbria-dependent activation of cell adhesion molecule expression in Porphyromonas gingivalis-infected endothelial cells. Infect. Immun. 70: 257-267. [Medline] [CrossRef]

23. Lamont, R. J. and Jenkinson, H. F. 1998. Life below the gum line: pathogenic mechanisms of Porphyromonas gingivalis. Microbiol. Mol. Biol. Rev. 62: 1244-1263. [Medline]

24. Lamont, R. J. and Jenkinson, H. F. 2000. Subgingival colonization by Porphyromonas gingivalis. Oral Microbiol. Immunol. 15: 341-349. [Medline] [CrossRef]

25. Landi, L., Amar, S., Polins, A. S. and Van Dyke, T. E. 1997. Host mechanisms in the pathogenesis of periodontal disease. Curr. Opin. Periodontol. 4: 3-10. [Medline]

26. Lenzo, J. C., O’Brien-Simpson, N. M., Orth, R. K., Mitchell, H. L., Dashper, S. G. and Reynolds, E. C. 2016. Porphyromonas gulae has virulence and immunological characteristics similar to those of the human periodontal pathogen Porphyromonas gingivalis. Infect. Immun. 84: $2575-2585$. [Medline] [CrossRef]

27. Listgarten, M. A. 1976. Structure of the microbial flora associated with periodontal health and disease in man. A light and electron microscopic study. J. Periodontol. 47: 1-18. [Medline] [CrossRef]

28. Love, D. N. 1995. Porphyromonas macacae comb. nov., a consequence of Bacteroides macacae being a senior synonym of Porphyromonas salivosa. Int. J. Syst. Bacteriol. 45: 90-92. [CrossRef]

29. Love, D. N., Bailey, G. D. and Bastin, D. 1992. Chromosomal DNA probes for the identification of asaccharolytic anaerobic pigmented bacterial rods from the oral cavity of cats. Vet. Microbiol. 31: 287-295. [Medline] [CrossRef]

30. Love, D. N., Bailey, G. D., Collings, S. and Briscoe, D. A. 1992. Description of Porphyromonas circumdentaria sp. nov. and reassignment of Bacteroides salivosus (Love, Johnson, Jones, and Calverley 1987) as Porphyromonas (Shah and Collins 1988) salivosa comb. nov. Int. J. Syst. Bacteriol. 42: 434-438. [Medline] [CrossRef]

31. Love, D. N., Johnson, J. L., Jones, R. F. and Calverley, A. 1987. Bacteroides salivosus sp. nov., an asaccharolytic, black-pigmented species from 
cats. Int. J. Syst. Bacteriol. 37: 307-309. [CrossRef]

32. Love, D. N., Johnson, J. L. and Moore, L. V. H. 1989. Bacteroides species from the oral cavity and oral-associated diseases of cats. Vet. Microbiol. 19: 275-281. [Medline] [CrossRef]

33. Love, D. N., Jones, R. F. and Calverley, A. 1984. Asaccharolytic black pigmented Bacteroides strains from soft tissue infections in cats. Int. J. Syst. Bacteriol. 34: 300-303. [CrossRef]

34. Love, D. N., Jones, R. F., Bailey, M., Johnson, R. S. and Gamble, N. 1982. Isolation and characterisation of bacteria from pyothorax (empyaemia) in cats. Vet. Microbiol. 7: 455-461. [Medline] [CrossRef]

35. Love, D. N., Vekselstein, R. and Collings, S. 1990. The obligate and facultatively anaerobic bacterial flora of the normal feline gingival margin. Vet. Microbiol. 22: 267-275. [Medline] [CrossRef]

36. Mallonee, D. H., Harvey, C. E., Venner, M. and Hammond, B. F. 1988. Bacteriology of periodontal disease in the cat. Arch. Oral Biol. 33: 677-683. [Medline] [CrossRef]

37. Maruyama, N., Mori, A., Shono, S., Oda, H. and Sako, T. 2018. Evaluation of changes in periodontal bacteria in healthy dogs over 6 months using quantitative real-time PCR. Pol. J. Vet. Sci. 21: 127-132. [Medline]

38. Nakagawa, I., Inaba, H., Yamamura, T., Kato, T., Kawai, S., Ooshima, T. and Amano, A. 2006. Invasion of epithelial cells and proteolysis of cellular focal adhesion components by distinct types of Porphyromonas gingivalis fimbriae. Infect. Immun. 74: 3773-3782. [Medline] [CrossRef]

39. Nassar, H., Chou, H. H., Khlgatian, M., Gibson, F. C. 3rd., Van Dyke, T. E. and Genco, C. A. 2002. Role for fimbriae and lysine-specific cysteine proteinase gingipain $\mathrm{K}$ in expression of interleukin-8 and monocyte chemoattractant protein in Porphyromonas gingivalis-infected endothelial cells. Infect. Immun. 70: 268-276. [Medline] [CrossRef]

40. Ogawa, T., Asai, Y., Hashimoto, M. and Uchida, H. 2002. Bacterial fimbriae activate human peripheral blood monocytes utilizing TLR2, CD14 and CD11a/CD18 as cellular receptors. Eur. J. Immunol. 32: 2543-2550. [Medline] [CrossRef]

41. Oishi, Y., Watanabe, K., Kumada, H., Ishikawa, E. and Hamada, N. 2012. Purification and characterization of a novel secondary fimbrial protein from Porphyromonas gulae. J. Oral Microbiol. 4: 19076. [CrossRef] [Medline]

42. Ozaki, K. and Hanazawa, S. 2001. Porphyromonas gingivalis fimbriae inhibit caspase-3-mediated apoptosis of monocytic THP-1 cells under growth factor deprivation via extracellular signal-regulated kinase-dependent expression of p21 Cip/WAF1. Infect. Immun. 69: 4944-4950. [Medline] [CrossRef]

43. Sarkiala, E., Asikainen, S., Wolf, J., Kanervo, A., Happonen, I. and Jousimies-Somer, H. 1993. Clinical, radiological and bacteriological findings in canine periodontitis. J. Small Anim. Pract. 34: 265-270. [CrossRef]

44. Sanguansermsri, P., Nobbs, A. H., Jenkinson, H. F. and Surarit, R. 2018. Interspecies dynamics among bacteria associated with canine periodontal disease. Mol. Oral Microbiol. 33: 59-67. [Medline] [CrossRef]

45. Slots, J. and Genco, R. J. 1980. Bacteroides melaninogenicus subsp. macacae, a new subspecies from monkey periodontopathic indigenous microflora. Int. J. Syst. Bacteriol. 30: 82-85. [CrossRef]

46. Umemoto, T. and Hamada, N. 2003. Characterization of biologically active cell surface components of a periodontal pathogen. The roles of major and minor fimbriae of Porphyromonas gingivalis. J. Periodontol. 74: 119-122. [Medline] [CrossRef]

47. van Winkelhoff, A. J. and de Graaff, J. 1991. Microbiology in the management of destructive periodontal disease. J. Clin. Periodontol. 18: 406-410. [Medline] [CrossRef]

48. Yilmaz, O., Watanabe, K. and Lamont, R. J. 2002. Involvement of integrins in fimbriae-mediated binding and invasion by Porphyromonas gingivalis. Cell. Microbiol. 4: 305-314. [Medline] [CrossRef]

49. Yoshimura, F., Takahashi, K., Nodasaka, Y. and Suzuki, T. 1984. Purification and characterization of a novel type of fimbriae from the oral anaerobe Bacteroides gingivalis. J. Bacteriol. 160: 949-957. [Medline] 